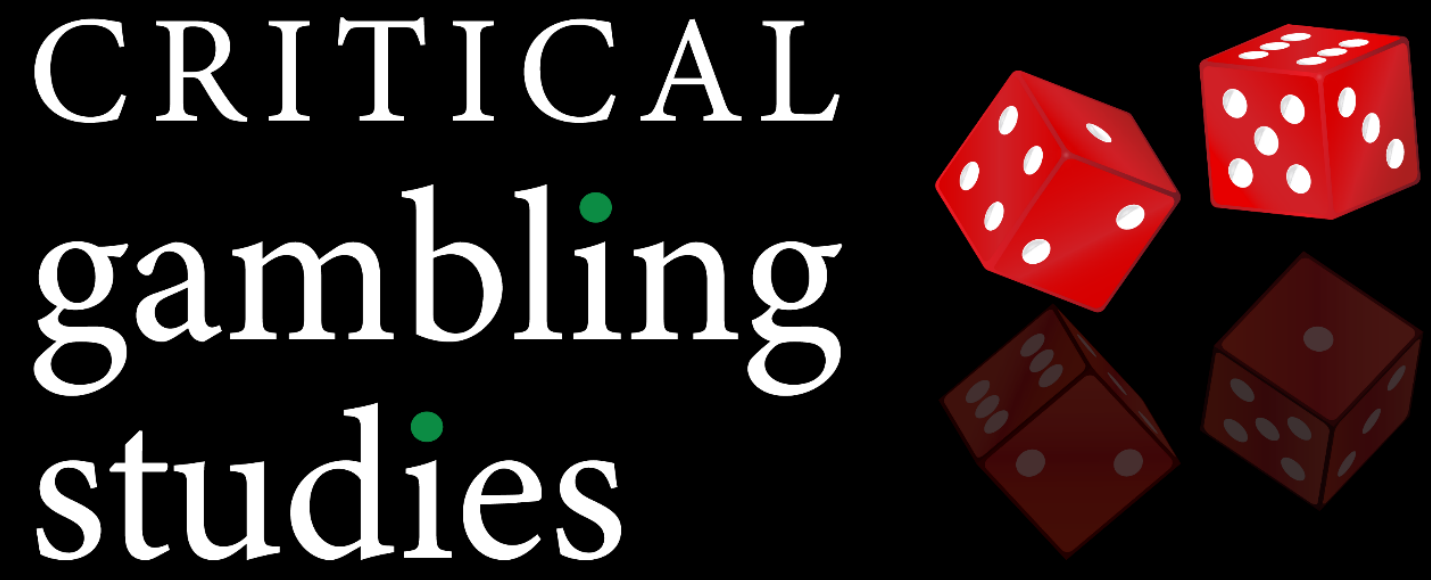

ISSN: 2563-190X. Available Open Access at https://criticalgamblingstudies.com

Responsible Gambling: A Scoping Review

Jennifer Reynolds, Sylvia Kairouz, Samantha Ilacqua, Martin French

APA Citation: Reynolds, J., Kairouz, S., llacqua, S., \& French, M. (2020). Responsible Gambling: A Scoping Review. Critical Gambling Studies, 1(1), 23-39.

https://doi.org/10.29173/cgs42

Article History:

Published April 2020 


\title{
Responsible Gambling: A Scoping Review
}

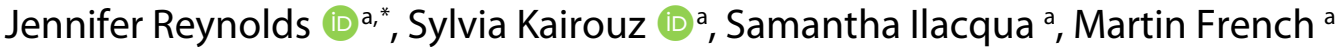

a Department of Sociology and Anthropology, Concordia University

\begin{abstract}
Gambling markets have drastically expanded over the past 35 years. Pacing this expansion has been the articulation of a governance framework that largely places responsibility for regulating gambling-related harms upon individuals. This framework, often defined with reference to the concept of responsible gambling (RG), has faced significant criticism, emphasizing public health and consumer protection issues. To study both the articulation and critique of the concept of responsible gambling, we conducted a 'scoping review' of the literature (Arksey \& O'Malley 2005). Literature was identified through searches on academic databases using a combination of search terms. Articles were independently reviewed by two researchers. Findings indicate 142 publications with a primary focus on responsible gambling, with a high volume of publications coming from the disciplinary backgrounds of the first authors representing the fields of psychology, business, and psychiatric medicine. Further, publication key themes address topics such as responsible gambling tools and interventions, corporate social responsibility and accountability, responsible gambling concepts and descriptions, and to a lesser extent, critiques of responsible gambling. The scoping review of the literature related to responsible gambling suggests the need to foster research conditions to invite more critical and interdisciplinary scholarship in an effort to improve public health and consumer protection.
\end{abstract}

Keywords: gambling, public health, scoping review, responsible gambling

While gambling has a long history in Western societies, gambling markets have drastically expanded over the past 35 years and have become a major source of income for national economies, securing approximately US\$ 430 billion dollars for government agencies and gambling operators in 2015 (Statista, 2018). With a rise in governmental control over gambling enterprises, intense pressure has been applied to state agencies and operators to protect citizens against gambling-related harms. In response, governments and operators have adopted responsible gambling (RG) frameworks and initiatives to prevent and reduce potential harms associated with gambling (Hing, 2010). Criticisms of the concepts of RG have been published, however, very little literature exists identifying and conceptually mapping the RG literature. To understand both the articulation and critique of the concept of responsible gambling, we conducted a 'scoping review' of the literature (Arksey \& O'Malley 2005). Thirty years of accumulated data on problem gambling and associated harms have firmly positioned gambling expansion as a public health issue (Canadian Public Health Association, 2000; Dalton, Stover, Vanderlinden, \&
Turner, 2012; Korn \& Shaffer, 1999). For example, the New Zealand government recognizes gambling as a public health issue and enacted a framework directly into their legislation (Gambling Act, 2003). Organizations such as Gambling Research Exchange Ontario (GREO, 2018) and the Victorian Responsible Gambling Foundation (2018) have enacted similar frameworks to guide strategic organizational objectives. However, while these frameworks are important for the understanding of gambling behavior as a public health issue, significant debates still exist. Despite general support for conceptualizing gambling as a public health issue, responsible gambling remains a dominant model. The role of generated knowledge and the influence of this model on the field as a whole, needs to be further understood.

\section{Construction of Responsible Gambling - The Reno Model}

Since 2004, the construction of responsible gambling has primarily been associated with a series of academic journal articles referred to as the Reno Model I-V

\footnotetext{
* Corresponding author. Address: Department of Anthropology and Sociology, Concordia University, Montreal, H3G 1M8, Quebec, Canada E-mail address:jenniferreynolds00@gmail.com
} 
(Blaszczynski et al., 2011; Blaszczynski, Ladouceur, \& Shaffer, 2004; Blaszczynski, Ladouceur, Nower, \& Shaffer, 2008; Collins et al., 2015; Ladouceur, Shaffer, Blaszczynski, \& Shaffer, 2017). As defined by Reno Model authors Blaszczynski, Ladouceur, and Shaffer, responsible gambling policies and practices are designed to prevent and reduce potential harms associated with gambling. They incorporate a diverse range of interventions aimed at promoting consumer protection, community/consumer awareness and education, and access to efficacious treatment. The Reno Model was positioned as a 'strategic framework' that would 'guide key stakeholders to develop socially responsible policies that are founded on sound empirical evidence rather than those that emerge solely in response to anecdotallybased socio-political influences' (Blaszczynski et al., 2004, p. 301). According to the Reno Model authors, responsible gambling policies ought to rest upon the principles of personal freedom to choose and informed choice, two of several significant differences in scope when compared to a public health model (Korn, Reynolds, \& Skinner, 2006). As an indication of the influence of the Reno Model, many current responsible gambling initiatives reflect principles centering on, for example, self- exclusion programs, player pre-commitment to limit time and monetary deposits, warning messages, problem gambling education programs, and treatment.

\section{The Responsible Gambling Debates}

Critical responses to the Reno Model, and responsible gambling policies and practices more generally, have sparked debates within the field of gambling studies, particularly with reference to the following key issues: 1 ) the definition of responsible gambling, 2) the evidentiary basis ostensibly demonstrating the efficacy of responsible gambling interventions, 3) the individualization of responsibility for harm-minimization, and 4) the difference across disciplinary perspectives. First, 'responsible' and 'problem' gambling are complex concepts (Campbell \& Smith, 2003; Miller, Thomas, Smith, \& Robinson, 2016), which over the years have left the responsible gambling movement lacking a clear definition and firm guidelines (Collins et al., 2015; Hancock \& Smith, 2017). A study by Miller et al. (2016), conducting a thematic analysis of responsible gambling discourses, found that while the term responsible gambling is ubiquitous on government and gambling industry websites, television campaigns, and responsible gambling materials, the term is rarely defined.

In addition to definitional issues, the evidentiary foundation of responsible gambling interventions has been called into question. The original Reno Model paper states the importance of scientific research to guide the development of gambling-related public policies (Blaszczynski et al., 2004). However, even Reno Model proponents now acknowledge that there is very little empirical evidential supporting the efficacy of responsible gambling interventions (Ladouceur et al., 2017). For example, most of the research on responsible gambling initiatives draws from research conducted in laboratory settings using simulated gambling with college students who are not representative of the general population, or more importantly, gamblers themselves (Gainsbury, Russell, \& Blaszczynski, 2014; Ladouceur et al., 2017). This has led responsible gambling critics to argue that responsible gambling frameworks merely represent a legitimation strategy used to normalize gambling, build markets, and offload any associated negative consequences onto individuals (Cosgrave \& Klassen, 2009; Hancock \& Smith, 2017; Livingstone \& Adams, 2016).

To date, responsible gambling initiatives tend to approach harm-minimization through a set of personalized behavioral control actions focused on individuals' gameplay (i.e., responsible gambling tools and interventions). This placement of the burden of responsibility on the individual has remained a major point of contention worldwide (Alexius, 2017; Campbell \& Smith, 2003; Hancock \& Smith, 2017; Hancock, Schellinck, \& Schrans, 2008; Reith, 2013). Some argue that the State and/or gambling providers should be expected to tend to gamblers' welfare, while others maintain that 'gamblers assume the burden of gambling responsibly and must consider the individual and social consequences of their gambling choices' (Blazczynski et al., 2011, p. 567). While several associations, such as the World Lottery Association, the Responsible Gambling Council, and the American Gambling Association, have instituted systems of certification or a Code of Conduct for the implementation and continuous monitoring of responsible gambling measures, critical positions question the foundational principles and practical applications of responsible gambling. They suggest that the construction of the 'responsible gambler' reflects a focus on the 'rational' individual to not only maintain control over their gambling but also resolve any problems that may arise because of their gameplay (Miller et al., 2016; Reith, 2008).

Finally, disciplinary perspectives that help to construct responsible gambling have sparked debate. Critics claim that both the terms responsible gambling and problem gambling are discursively constructed and influenced by powerful institutions (Miller et al., 2016; Reith, 2008). It has been stated that 'the field of gambling studies is closed and tightly controlled,' dominated by the fields of psychology, psychiatry, and medicine (Cassidy, Loussouarn, \& Pisac, 2013). As Reith (2013) indicates, 'responsibility is based on the possession of power and implies accountability - to another and for something' ( $p$. 149). However, with respect to responsible gambling, it is difficult to ascertain the nature of the accountability relationship (Alexius, 2017; Smith \& Rubenstein, 2011). 
Gambling operators have a lot at stake if discussions about gambling and gambling-related harms are focused beyond the 'rational' individual. As indicated in the original Reno model paper, the framework emerged from collegial roundtable meetings held in Reno, funded by government and commercial gambling interests to develop effective responsible gambling principles and schemes (Blaszczynski et al., 2004). As Hancock and Smith (2017) argue, governments and commercial gambling operators welcome the Reno Model because, with respect to accountability, very little is expected from them.

Given the above points of debate, there is a need to identify and conceptually map the existing literature in order to understand how the notion of responsible gambling has been driven by the scientific literature and, in turn, the public health implications of such. As a method, scoping studies 'map rapidly the key concepts underpinning a research area and the main sources and types of evidence available, and can be undertaken as stand-alone projects in their own right, especially where an area is complex or has not been reviewed comprehensively' (Arksey \& O'Malley, 2005, p. 21).

\section{Objectives}

Given the ongoing debates around responsible gambling and the dearth of comprehensive reviews of the responsible gambling literature, a scoping study was an ideal first step towards developing a better understanding of the nature and scope of the existing literature. To fill the knowledge gap, our objectives for the scoping review were to:

1. Identify the existing literature related to responsible gambling;

2. Conceptually map the literature according to year and type of publication, country of first author, discipline, main themes addressed, and media mentions;

3. Determine gaps in the literature and areas for future inquiry that would contribute to abetter understanding of responsible gambling.

\section{Methods}

We conducted a scoping study using the methodological framework set out by Arksey and O'Malley (2005). At the initial stages of our inquiry, we developed search terms and inclusion/exclusion criteria. However, given the contested definitions of responsible gambling outlined above, a flexible, iterative process was necessary. As a result, search terms and criteria were reviewed and revised as required.

\section{Literature Search}

With the guidance of a university librarian, literature was identified from various academic databases (i.e., Scopus, Web of Science, PsychInfo, SOCIndex, Academic Search Compete, and Business Source Complete). Google Scholar was found to be an unrealistic database for conducting a scoping review because of the massive reference returns obtained, the high volume of duplicates, and its lack of functionality in exporting citations. Using a combination of truncated base and search terms (see Table 1), our search was conducted on two occasions (February 5-15, 2017 and April 6-7, 2018), yielding a combined total of 14,712 hits. We eliminated 8,147 references, which were deemed to be duplicates, and an additional 6,100 that were deemed not to adhere to the following inclusion criteria: a) English or French language, b) abstract must contain keywords such as 'responsible gambling', 'problem gambling' (+ responsib*), gaming (+ responsib*), play (+ responsib*), harm (+ responsib*), risk (+ responsib*), prevention (+ responsib*), and c) responsible gambling must be a central objective of the article. Conference papers, articles not related to gambling, and articles that mention gambling but are not focused on responsible gambling as a main objective were excluded. The remaining 465 abstracts were then validated through a two-tier inter-rater reliability process. First, two of us (JR and SI) independently reviewed the remaining 465 abstracts to further narrow down our references to a manageable final database. During the review process, references were marked as either 'include,' 'exclude,' or 'maybe.' Those articles were then independently reviewed by the other researchers (SK and MF). There was full agreement on the references to be excluded and an agreement rate of $78 \%$ on references to be included. Divergent cases were discussed, and inclusion/exclusion was arrived at through consensus.

A set of RefWorks fields were then coded for each reference, derived from the abstracts and full-text (when required). In total, twenty-two variables were coded for. Specifically, twelve manuscript descriptive variables were documented (e.g., title, journal, year, university affiliation, country, discipline, authors, theme, keywords). Where available, six citation variables (e.g., citations, blog posts, Twitter tweets, Facebook posts, Mendeley mentions), and three location variables (e.g., datasource, URL, DOI) were coded for. Finally, RG frequencies were coded. RG frequencies took into consideration the number of time "RG" or "responsible gambling" appeared within the article, broken down by title, abstract, keyword, main body, and references. Final references were then imported from RefWorks into Excel and SPSS for analysis. 


\section{Table 1}

Search Terms.

\begin{tabular}{ll}
\hline Base Term & AND \\
\hline $\begin{array}{l}\text { OR } \\
\text { "responsible gambling" }\end{array}$ & \\
\hline responsib* gambler" & gambl* \\
gambling & monitoring, OR \\
& regulation, OR \\
& governance, OR \\
& "harm minimization", OR \\
& "harm reduction", OR \\
\hline responsibility & leisure \\
"social costs" & "gambling prevention", OR \\
"gambling addiction", OR \\
control & "problem gambling", OR \\
"gambling problem", OR \\
harm & "gambler", OR \\
risk & "game consumption", OR \\
\hline
\end{tabular}

\section{Table 2}

Codebook.

\begin{tabular}{|c|c|}
\hline Variable & Description \\
\hline List & References associated with either the primary or secondary list acquired through scoping review \\
\hline Type & Type of periodical \\
\hline Theme & Theme applied to reference \\
\hline Authors & All authors listed on the publication \\
\hline Title & Title of the article published \\
\hline Periodical & Name of journal or book that the article was published in \\
\hline Year & The year that the article was published \\
\hline Affiliation & The University department or organization connected with the first author \\
\hline Country & Country affiliated with1st author \\
\hline Discipline & Field of study affiliated with the first author \\
\hline Blog & Number of blog posts associated with the reference \\
\hline Twitter & Number of tweets associated with the reference \\
\hline Facebook & Number of mentions in Facebook posts \\
\hline Mendeley & Number of mentions in Mendeley \\
\hline Benchmark & Compares citation counts to other references in similar disciplinary area \\
\hline Citations & Number of times the reference has been cited \\
\hline Keywords & Author chosen keywords associated to article \\
\hline Abstract & Article abstract \\
\hline Datasource & Database that reference was found \\
\hline URL & Associated web address \\
\hline DOI & Associated digital object identifier \\
\hline$R G^{a}$ frequencies & $\begin{array}{l}\text { Number of time "RG" or "responsible gambling" appeared within the article, broken down by title, abstract, } \\
\text { keyword, main body (intro, methods, results, discussion/conclusion), and references }\end{array}$ \\
\hline
\end{tabular}




\section{Responsible Gambling Screening within the Primary Set of Articles}

To delineate how and where the authors mention responsible gambling in the primary set of articles, a systematic search within the available pdfs was conducted using the terms 'RG' and 'responsible gambling.' Specifically, we calculated the number of occurrences of responsible gambling within the article to determine an overall total and a total by sections (e.g., intro, methods, results, discussion). Seven articles were omitted from the analysis because we were unable to obtain a complete copy of the paper to review. Results were checked for accuracy and validity of responsible gambling terms. For published articles that did not adhere to the traditional manuscript format, search results were calculated and included in the overall number of mentions and only in specific sections where clearly defined.

\section{Results}

Our search yielded a final database of 172 articles. Specifically, our original search of six academic databases, generated 14,712 articles. Duplications were removed and abstracts were screened for language (English, French). In total, 465 articles were then reviewed according to our inclusion/exclusion criteria. Upon reviewing the final full-text articles, it was deemed that 142 references adhered to our inclusion criterion of having responsible gambling as a central objective of the article. The remaining 30 references were categorized as secondary articles that we felt should nonetheless be examined as part of the study despite responsible gambling being a component of the study but not the main focus. For example, articles addressing topics such as advertising and marketing, along with regulation were included in this subset. We present the findings of the scoping review conceptual mapping in Table 3.

Published articles on responsible gambling span between 2001-2017, with the majority being peerreviewed journal articles, followed by journal editorials, books and book sections, and a monograph. Among the primary articles, the most popular publication year was $2017(n=20,14.08 \%)$, followed by 2009 and $2014(n=14$, $11.29 \%)$. The most popular publication years for the secondary articles were equally 2015 and $2017(n=6$, $20.00 \%)$. Articles represented a wide spectrum of countries, however, over $75 \%$ of the primary publications were authored in four countries: Australia $(n=49$, $35.00 \%)$, Canada ( $n=31,22.14 \%)$, England ( $n=14$, $10.00 \%)$, and the United States ( $n=12,8.57 \%)$. Further, we found that just under half of the primary articles originate from the discipline of psychology ( $n=62,43.66 \%)$, followed by business ( $n=44,30.99 \%)$. Our secondary articles originated predominantly from the discipline of business $(n=10,33.33 \%)$. Other articles derive from disciplines such as medicine $(n=6,20 \%)$, as well as law and psychology ( $n=4,16.67 \%)$.

Table 3

Results of Conceptual Mapping.

\begin{tabular}{|c|c|c|c|c|}
\hline \multirow[b]{2}{*}{ Coding categories } & \multicolumn{2}{|c|}{ Primary $(n=142)$} & \multicolumn{2}{|c|}{ Secondary $(n=30)$} \\
\hline & $N$ & $\%$ & $N$ & $\%$ \\
\hline \multicolumn{5}{|l|}{ Year of publication } \\
\hline 2001 & 1 & 0.70 & & \\
\hline 2002 & 1 & 0.70 & & \\
\hline 2003 & 2 & 1.41 & 1 & 3.33 \\
\hline 2004 & 4 & 2.82 & 1 & 3.33 \\
\hline 2005 & 11 & 7.75 & & \\
\hline 2006 & 5 & 3.52 & & \\
\hline 2007 & 3 & 2.11 & & \\
\hline 2008 & 11 & 7.75 & 2 & 6.67 \\
\hline 2009 & 14 & 9.86 & & \\
\hline 2010 & 2 & 1.41 & 1 & 3.33 \\
\hline 2011 & 8 & 5.63 & 2 & 6.67 \\
\hline 2012 & 10 & 7.04 & 2 & 6.67 \\
\hline 2013 & 11 & 7.75 & 5 & 16.67 \\
\hline 2014 & 14 & 9.86 & & \\
\hline 2015 & 13 & 9.15 & 6 & 20.00 \\
\hline 2016 & 12 & 8.45 & 4 & 13.33 \\
\hline 2017 & 20 & 14.08 & 6 & 20.00 \\
\hline \multicolumn{5}{|l|}{ Type of publication } \\
\hline Book, section & 1 & 0.70 & 4 & 13.33 \\
\hline Book, whole & 2 & 1.41 & & \\
\hline Journal article & 136 & 95.77 & 25 & 83.33 \\
\hline Journal editorial & 2 & 1.41 & 1 & 3.33 \\
\hline Monograph & 1 & 0.70 & & \\
\hline \multicolumn{5}{|l|}{ Country of first author } \\
\hline Africa & 1 & 0.71 & & \\
\hline South Africa & 1 & 0.71 & & \\
\hline Americas & 43 & 30.71 & 13 & 44.83 \\
\hline Canada & 31 & 22.14 & 2 & 6.90 \\
\hline United States & 12 & 8.57 & 11 & 37.93 \\
\hline Asia & 11 & 7.85 & & \\
\hline China & 2 & 1.43 & & \\
\hline Hong Kong & 1 & 0.71 & & \\
\hline Japan & 1 & 0.71 & & \\
\hline Singapore & 2 & 1.43 & & \\
\hline South Korea & 4 & 2.86 & & \\
\hline Europe & 33 & 17.14 & 11 & 37.94 \\
\hline Austria & 5 & 3.57 & & \\
\hline England & 14 & 10.00 & 5 & 17.24 \\
\hline Finland & 2 & 1.43 & 2 & 6.90 \\
\hline France & 3 & 2.14 & 1 & 3.45 \\
\hline Germany & & & 1 & 3.45 \\
\hline Netherlands & 1 & 0.71 & & \\
\hline Norway & 1 & 0.71 & & \\
\hline Portugal & & & 1 & 3.45 \\
\hline Scotland & 3 & 2.14 & 1 & 3.45 \\
\hline Slovenia & 1 & 0.71 & & \\
\hline Sweden & 2 & 1.43 & & \\
\hline Wales & 1 & 0.71 & & \\
\hline Oceania & 51 & 36.43 & 6 & 20.69 \\
\hline Australia & 49 & 35.00 & 5 & 17.24 \\
\hline New Zealand & 2 & 1.43 & 1 & 3.45 \\
\hline Thailand & 1 & 0.71 & & \\
\hline
\end{tabular}


Articles were also classified according to main themes: a) corporate social responsibility and accountability, b) context/predictors, c) critical, d) governance, e) responsible gambling concepts and descriptives, f) responsible gambling experience and behaviors, g) responsible gambling tools and interventions, h) regulation, i) advertising and marketing, and j) harm minimization. For the full descriptions of themes, see Table 4. Not surprisingly, the most predominant theme that emerged from the primary articles was responsible gambling tools and interventions $(n=73,51.41 \%)$, followed by manuscripts describing responsible gambling concepts and descriptives ( $n=15,10.56 \%)$, and articles critical of responsible gambling $(n=15,10.56 \%)$. The majority of the secondary articles addressed corporate social responsibility and accountability $(n=12,40 \%)$. Cross tabulations were then conducted to examine themes broken down by discipline and country. Cross tabulations results are presented in Tables 5 and 6.

\section{Table 4}

Description of Themes.

\begin{tabular}{ll}
\hline Themes & Description \\
\hline CSR ${ }^{\text {\& } ~ a c c o u n t a b i l i t y ~}$ & $\begin{array}{l}\text { Articles that primarily focus on corporate social responsibility and accountability, as an implication } \\
\text { of RG. }\end{array}$ \\
\hline Context/predictors & $\begin{array}{l}\text { Articles that examine risk and protective factors associated with gambling, player characteristics, } \\
\text { as well as screening tools in the implementation of RG. }\end{array}$ \\
\hline Critical & $\begin{array}{l}\text { Articles that are critical of RG and/or examine RG through a critical social science and humanities } \\
\text { perspective. }\end{array}$ \\
\hline Governance & Articles that focus on the implementation and governance of RG. \\
\hline RG concepts \& descriptives & Articles that discuss principle concepts and descriptions of RG. \\
\hline RG experience \& behaviors & Articles that discuss player experiences and behaviors of RG. \\
\hline RG tools \& interventions & $\begin{array}{l}\text { Articles that focus on specific RG tools and interventions to minimize gambling-related harms (e.g. } \\
\text { pop up messaging, pre-commitment, self-exclusion). }\end{array}$ \\
\hline Regulation & Articles that focus on the legal and regulation of RG. \\
\hline Advertising \& marketing & Articles that focus on gambling advertising and marketing primarily, in response to RG. \\
\hline Harm minimization & Articles that primarily focus on RG in the prevention of gambling-related harms. \\
\hline a CSR = corporate social responsibility \\
${ }^{b}$ RG = responsible gambling &
\end{tabular}




\section{Table 5}

Results of Crosstabs (Primary Articles).

\begin{tabular}{|c|c|c|c|c|c|c|c|c|c|}
\hline & 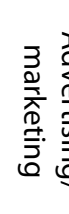 & గ్రి & 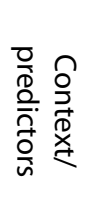 & 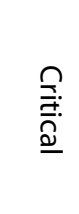 & 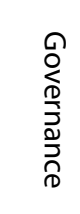 & 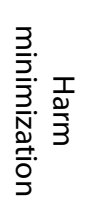 & 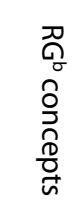 & 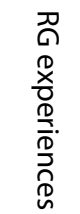 & $\begin{array}{l}\text { ग0 } \\
\text { + } \\
\text { 음 }\end{array}$ \\
\hline & $N$ & $N$ & $N$ & $N$ & $N$ & $N$ & $N$ & $N$ & $N$ \\
\hline \multicolumn{10}{|l|}{ Discipline } \\
\hline Anthropology & & & 1 & & & & & & \\
\hline Business & 1 & 8 & 1 & 5 & 1 & & 6 & 6 & 16 \\
\hline Computer Science & & & & & & & 1 & & \\
\hline Criminology & & & & 1 & & & & & \\
\hline Law & & 2 & & & & & & & \\
\hline Medicine & & & 1 & & 1 & & 2 & & 4 \\
\hline Other & & & & & & & & & 3 \\
\hline Psychology & & 2 & 1 & 1 & 2 & & 5 & 5 & 46 \\
\hline Public health & & 1 & & 4 & & 1 & & 2 & 2 \\
\hline Public policy & & 2 & & 2 & & & 1 & & \\
\hline Sociology & & & & 2 & 1 & & & & 2 \\
\hline \multicolumn{10}{|l|}{ Country } \\
\hline Australia & 1 & 3 & 3 & 8 & 1 & & 7 & 6 & 20 \\
\hline Austria & & & & & & & & & 5 \\
\hline Canada & & 1 & & 1 & 1 & & 3 & 2 & 23 \\
\hline China & & 1 & & & & & & & 1 \\
\hline England & & 1 & & 1 & 1 & & 2 & 1 & 8 \\
\hline Finland & & & & 2 & & & & & \\
\hline France & & & & & & 1 & 1 & & 1 \\
\hline Hong Kong & & 1 & & & & & & & \\
\hline Japan & & & & & & & & & 1 \\
\hline Netherlands & & & & 1 & & & & & \\
\hline New Zealand & & 1 & & & & & & & 1 \\
\hline Norway & & & & & & & & & 1 \\
\hline Scotland & & & & 2 & & & & & 1 \\
\hline Singapore & & 1 & & & & & & & \\
\hline Slovenia & & & & & 1 & & & & \\
\hline South Africa & & & & & & & & 1 & \\
\hline South Korea & & 1 & & & & & & 2 & 1 \\
\hline Sweden & & 1 & & & & & & & 1 \\
\hline Switzerland & & & & & 1 & & & & \\
\hline Thailand & & & & & & & & & 1 \\
\hline United States & & 1 & 1 & & & & 1 & & 8 \\
\hline Wales & & 1 & & & & & & & \\
\hline
\end{tabular}

${ }^{a} \mathrm{CSR}=$ corporate social responsibility.

${ }^{\mathrm{b}} \mathrm{RG}=$ responsible gambling 
Table 6

Result of Crosstabs (Secondary Articles).

\begin{tabular}{|c|c|c|c|c|c|}
\hline & $\begin{array}{l}\text { Advertising/ } \\
\text { marketing }\end{array}$ & $\begin{array}{c}\operatorname{CSR}^{\mathrm{a}} \& \\
\text { Accountability }\end{array}$ & Critical & $\begin{array}{c}\text { Harm } \\
\text { minimization }\end{array}$ & Regulation \\
\hline & $N$ & $N$ & $N$ & $N$ & $N$ \\
\hline \multicolumn{6}{|l|}{ Discipline } \\
\hline Business & 3 & 6 & & 1 & \\
\hline Law & & & & & 4 \\
\hline Medicine & 1 & 2 & & 3 & \\
\hline Psychology & 1 & 1 & & 2 & \\
\hline Public health & & 2 & & & \\
\hline Public policy & & 1 & & & 1 \\
\hline Sociology & 1 & & 1 & & \\
\hline \multicolumn{6}{|l|}{ Continent } \\
\hline Americas & 3 & 5 & & 3 & 2 \\
\hline Europe & 1 & 1 & 1 & 3 & 3 \\
\hline Oceania & 2 & 4 & & & \\
\hline
\end{tabular}

Finally, we sought to identify where and how often the authors mentioned responsible gambling within the primary articles, broken down by theme. Results are presented in Table 7. Across all themes, the highest concentration of at least one mention of responsible gambling within the articles were found within the introduction $(84.54 \%)$ and discussion (76.32\%) sections. Of particular interest is that the lowest concentration of mentions occurred in the keywords (46.88\%) despite high concentrations in both the introduction and discussion of the papers. The concentration of responsible gambling mentions within the methods and results/findings section of the articles were $57.30 \%$ and $52.87 \%$, respectively. Broken down by theme, the highest concentration of responsible gambling mentions was, unsurprisingly, found within responsible gambling concepts and descriptives (39.47\%).

Table 7

Mentions of Responsible Gambling by Themes (Primary Articles Only).

\begin{tabular}{|c|c|c|c|c|c|c|c|c|c|c|}
\hline \multirow[b]{2}{*}{ Themes } & \multicolumn{2}{|c|}{$\mathrm{RG}^{\mathrm{a}}$ mentions } & \multicolumn{8}{|c|}{ At least one mention of RG (\%) } \\
\hline & Mean & Max & Title & Abstract & Keywords & Intro. & M. & $\begin{array}{l}\text { Results/ } \\
\text { findings }\end{array}$ & $\begin{array}{l}\text { Discussion/ } \\
\text { conclusion }\end{array}$ & Ref. \\
\hline All themes $(n=135)$ & 30.11 & 162 & 35.82 & 74.81 & 46.88 & 84.54 & 57.30 & 52.87 & 76.32 & 61.19 \\
\hline $\begin{array}{l}\text { RG tools \& } \\
\text { interventions }(n=71)\end{array}$ & 28.92 & 162 & 40.85 & 76.06 & 57.14 & 92.73 & 55.77 & 49.02 & 85.48 & 64.79 \\
\hline $\begin{array}{l}\text { RG concepts \& } \\
\text { descriptives }(n=15)\end{array}$ & 39.47 & 112 & 40.00 & 73.33 & 46.15 & 44.44 & 37.50 & 50.00 & 41.67 & 40.00 \\
\hline Critical $(n=14)$ & 26.50 & 99 & 14.29 & 69.23 & 15.38 & 80.00 & 100.00 & 100.00 & 77.78 & 64.29 \\
\hline $\begin{array}{l}\mathrm{CSR}^{\mathrm{b}} \& \\
\text { accountability } \\
(n=13)\end{array}$ & 35.23 & 111 & 38.46 & 58.33 & 41.67 & 72.73 & 55.56 & 44.44 & 58.33 & 53.85 \\
\hline $\begin{array}{l}\text { RG experience \& } \\
\text { behaviors }(n=11)\end{array}$ & 34.91 & 98 & 50.00 & 90.00 & 40.00 & $\begin{array}{l}100.0 \\
0\end{array}$ & 88.89 & 88.89 & 100.00 & 60.00 \\
\hline Governance $(n=5)$ & 8.40 & 22 & - & 50.00 & 25.00 & 66.67 & 33.33 & 33.33 & 50.00 & 40.00 \\
\hline $\begin{array}{l}\text { Context/predictors } \\
(n=4)\end{array}$ & 35.25 & 93 & 25.00 & 100.00 & 25.00 & $\begin{array}{l}100.0 \\
0\end{array}$ & 33.33 & 33.33 & 66.67 & 100.00 \\
\hline $\begin{array}{l}\text { Advertising \& } \\
\text { marketing }(n=1)\end{array}$ & 22.00 & 22 & - & 100.00 & 100.00 & $\begin{array}{l}100.0 \\
0\end{array}$ & 100.00 & 100.00 & 100.00 & 100.00 \\
\hline $\begin{array}{l}\text { Harm minimization } \\
(n=1) \\
\text { Regulation }(n=0)\end{array}$ & 2.00 & 2 & - & 100.00 & - & - & - & - & - & 100.00 \\
\hline
\end{tabular}

Note. RG meanings were not analyzed, only frequency of mentions. Seven articles were omitted from the analysis because of unavailability.

${ }^{a} \mathrm{RG}=$ responsible gambling

${ }^{\mathrm{b}} \mathrm{CSR}=$ corporate social responsibility 


\section{Discussion}

The aim of our study was to identify and conceptually map the existing literature as a means to determine the gaps and suggest areas for future inquiry. Given the calls over the years to better understand responsible gambling, this review compliments the existing literature by identifying disciplinary origins and key themes within the articles that directly frame academic discussion and practice.

Dr. Jonathan Mann, a public health pioneer, famously proclaimed that the way you define a problem will determine what you do about it (D'oronzio, 2001). As the founding director of the World Health Organization Global Program on Acquired Immunodeficiency Syndrome (AIDS), his bold directive called for a reexamination of professional assumptions. Our findings illustrate that much of the responsible gambling literature is derived from the disciplines of psychology (43.66\%) and business (30.99\%), thematically linked to responsible gambling tools and interventions, and directed towards the individual gambler as a way to 'responsibilize' their 'at-risk' or 'pathological' level of gameplay. Given that gambling expansion has long been identified as a public health issue, this is an important result if the field wants to move towards a socio-cultural perspective that does not place the lion's share of the burden for addressing gambling-related harms upon individuals. Further, it is noteworthy that our findings point to the lack of public health publications on responsible gambling. This suggests that the literature on responsible gambling might be lacking research into the true public health implications of responsibilization.

These results are reflective of previous empirical findings. When trying to understand evidence, Cassidy et al. (2013), found that the majority of researchers who selfidentify as Gambling Studies scholars are psychologists by background and that key journals within the field (i.e., Journal of Gambling Studies, International Gambling Studies), have $56 \%$ of their editorial board members coming from the disciplinary backgrounds of psychology, psychiatry, and medicine. Further, Cassidy and colleagues (2013) note that 'although both journals claim to be interdisciplinary, the majority of articles published focus on excessive gambling represented as a psychological problem, substantiated largely through quantitative methodologies' (p. 49).

In another study, Alexius (2017) concludes that a lack of critical opposition against the individual-centered solutions to problems has led to the reproduction of the hegemonic idea of the responsible gambler throughout the field. She calls for a self-reflexive, critical analysis of current responsible gambling measures as a way to understand contemporary gambling policies and practices.

Recent research on gambling-related harms, discusses how the differences in approaches and disciplinary perspectives have resulted in a lack of a robust, agreed upon definition of harms in the field of gambling (Browne et al., 2016). Browne et al. (2016) challenge the current individualized, "problem gambler" focus, illustrating how harms are distributed across a broad spectrum of gambling behaviours, in addition to, showing a significant burden of wellbeing to the community. While they acknowledge the important role that problem gambling measurements can have, the authors argue that they are not designed to assess the broad range of harms experienced, including exposure to a variety of gamblingrelated harms (Browne at al., 2016).

As a result of the lack of efficacy of many responsible gambling measures, there has been a call to re-frame responsible gambling with consumer protection strategies in which gambling providers have a duty of care toward patrons and employees, public safety, and with regards to social impact (Hancock, 2011). As Alexius argues, when it comes to understanding responsibility, we need to 'broaden our perspective in both time and space, to examine different ways in which responsibility problems and those responsible are created and shaped, rather than identified' (Alexius, 2017, p. 464), which aligns with a critical public health approach to gambling.

By not fully understanding responsible gambling as well as the public health implications of gambling, the field remains focused on only one element of the public health triad to understand gambling (Korn \& Shaffer, 1999) - the individual. This significant gap in the responsible gambling literature raises important questions. What is the role of responsible gambling in population-level prevention? Further, how does responsible gambling address the notion of public good and the merits of investing funds into the implementation of responsible gambling measures that are not deemed efficient (Harris \& Griffiths, 2017; Hancock \& Smith, 2017; Maclaren, 2016; Schellinck \& Schrans, 1998; Schüll, 2012)?

A key objective of this study was to determine gaps in the literature related to responsible gambling to highlight important areas for further inquiry. As discussed, the scoping review reveals a paucity of critical literature on responsible gambling. For this scoping review, we use the term critical to refer to articles that are critical of RG and/or examine RG through a critical social science and humanities lens. Thus, our interpretation would emphasize the need to foster research conditions to invite more critical and interdisciplinary scholarship in an effort to broaden the debate about how best to prevent gambling-related harms. A socio-cultural approach to understanding gambling and gambling-related harms 'requires a panoramic view of gambling in society,' (Campbell \& Smith, 2003, p. 141) analyzing its benefits and costs, as well as identifying multi-level strategies for action and points of intervention across a gambling risk continuum (Korn, Gibbins, \& Azmier, 2003). To truly understand gambling and gambling-related harms, 
scholarship must move beyond the individual biological and behavioral dimensions to include a more integrated and critical examination of the gambling environment and the games themselves (Korn \& Shaffer, 1999).

Research shows us that gambling harms burden the wellbeing of the community (Browne et al., 2016). A more systematic approach moves the field beyond the current tensions that exist between the individual versus a population-based approach. A notable finding of this review was the absence of responsible gambling articles in the primary list examining themes such as advertising and marketing and responsible gambling-related policies. The environment is a crucial component of the public health triad to understand gambling and gamblingrelated harms. Despite increasing concerns about the proliferation of marketing for gambling products and services, we see very limited research exploring the influence of marketing strategies on gambling attitudes and consumption, as well as the flip side, on strategies that may be used to reduce marketing-related risks (Deans, Thomas, Derevensky, \& Daube, 2017). This is important to note, as marketing and advertising plays a strong role in the normalization of gambling, impacting gambling attitudes and behaviors of both youth and adults (Deans et al., 2017; Korn, Reynolds, \& Hurson, 2008; Monaghan, Derevensky, \& Sklar, 2008). This absence also speaks to the continued focus of the literature on the individual.

This scoping review adds a much-needed perspective on the available literature on responsible gambling. However, several limitations should be noted. First, a limitation to this study is the bounded scope of our research search strategy, in particular, the search terms used and our choice of databases. While regular consultation with the university librarian was conducted, it is possible that we may not have captured all relevant literature on this topic or adequately captured the number of responsible gambling mentions in the primary articles.

Further, scoping reviews are more methodological in nature, posing potential issues in synthesizing the data (Arksey \& O'Malley, 2005). As a result, the methodology provides little guidance in constructing a narrative of the research beyond the descriptive level. For instance, previous research and academic discussions highlight the issue of funding sources with respect to gambling research (Adams, 2007; Cassidy et al., 2013; Hancock \& Smith, 2017; Livingstone \& Adams, 2016). This is an important topic to explore and understand, however, exploring this link goes beyond the scope of this review. A deeper level of analysis of the individual articles would be required, as many of the databases do not offer funding source information, and not all authors report funding sources within the article. Finally, analytic difficulties were experienced when examining the frequency of RG within the studies. For example, this scoping review only delineated the number of times the term was mentioned. It should be noted that authors may be using the term RG in different contexts and with different understandings of the term. Future research could build upon the findings of this scoping review to further map out the latest responsible gambling research contributions to field. Further research might also analyze how the concept of responsible gambling emerged and map the normative discourse and rationalities that have dominated the logics and practices of institutions involved in responsible gambling.

\section{References}

Adams, P. J. (2007). Assessing whether to receive funding support from tobacco, alcohol, gambling and other dangerous consumption industries. Addiction, 102(7), 1027-1033.

Alexius, S. (2017). Assigning responsibility for gambling-related harm: Scrutinizing processes of direct and indirect consumer responsibilization of gamblers in Sweden. Addiction Research \& Theory, 25(6), 462-475. doi: 10.1080/16066359.2017.1321739

Arksey, H., \& O'Malley, L. (2005). Scoping studies: Towards a methodological framework. International Journal of Social Research Methodology, 8(1), 19-32. doi: 10.1080/1364557032000119616

Blaszczynski, A., Collins, P., Fong, D., Ladouceur, R., Nower, L., Shaffer, H. J., ... \& Venisse, J. L. (2011). Responsible gambling: General principles and minimal requirements. Journal of Gambling Studies, 274), 565573. doi: $10.1007 / \mathrm{s} 10899-010-9214-0$

Blaszczynski, A., Ladouceur, R., \& Nower, L. (2008). Informed choice and gambling: Principles for consumer protection. The Journal of Gambling Business and Economics, 2(1), 103-118. doi: 10.5750/jgbe.v2i1.527

Blaszczynski, A., Ladouceur, R., \& Shaffer, H. J. (2004). A science-based framework for responsible gambling: The Reno Model. Journal of Gambling Studies, 20(3), 301-317. doi: 10.1023/B:JOGS.0000040281.49444.e2

Browne, M., Langham, E., Rawat, V., Greer, N., Li, E., Rose, J., ... \& Bryden, G. (2016). Assessing gambling harm in Victoria: $A$ public health perspective. Retrieved from https://prism.ucalgary.ca/handle/1880/51519

Campbell, C. S., \& Smith, G. J. (2003). Gambling in Canada_From vice to disease to responsibility: A negotiated history. Canadian Bulletin of Medical History, 201), 121-149. doi: 10.3138/cbmh.20.1.121

Canadian Public Health Association. (2000). Gambling expansion in Canada: An emerging public health issue. CPHA Health Digest, XXIM10), 1-4. doi: 10.11575/PRISM/9569

Cassidy, R., Loussouarn, C., \& Pisac, A. (2013). Fair game: Producing gambling research. Retrieved from

https://www.gold.ac.uk/gamblingineurope/report/

Collins, P., Blaszczynski, A., Ladouceur, R., Shaffer, J., Fong, D., \& Venisse, J. L. (2015). Responsible gambling: Conceptual considerations. Gaming Law Review and Economics, 19(8), 594-599.

Cosgrave, J., \& Klassen, T. (2009). Casino state: Legalized gambling in Canada. Toronto, ON: University of Toronto Press.

D'oronzio, J. C. (2001). The integration of health and human rights: An appreciation of Jonathan M. Mann. Cambridge Quarterly of Healthcare Ethics, 103), 231-240. doi: 10.1017/S0963180101003036 
Dalton, A., Stover, A., Vanderlinden, L., \& Turner, N. E. (2012). The health impacts of gambling expansion in Toronto. Retrieved from https://www.greo.ca/Modules/EvidenceCentre/Details/healthimpacts-gambling-expansion-toronto

Deans, E. G., Thomas, S. L., Derevensky, J., \& Daube, M. (2017). The influence of marketing on the sports betting attitudes and consumption behaviours of young men: Implications for harm reduction and prevention strategies. Harm Reduction Journal, 14(1), 5. doi: 10.1186/s12954-017-0131-8

Gainsbury, S. M., Russell, A., \& Blaszczynski, A. (2014). Are psychology university student gamblers representative of non-university students and general gamblers? A comparative analysis. Journal of Gambling Studies, 3011), 11-25. doi: 10.1007/s10899-012-9334-9

Gambling Act (2003). Gambling Act. Retrieved from http://www.legislation.govt.nz/act/public/2003/0051/latest/whole.ht ml\#DLM210255

Gambling Research and Exchange Ontario (GREO). Gambling from a public health perspective. Retrieved from http://www.greo.ca/en/publichealth.aspx

Hancock, L., \& Smith, G. (2017). Critiquing the Reno Model I-IV international influence on regulators and governments (20042015) - the distorted reality of "responsible gambling". International Journal of Mental Health and Addiction, 15(6), 1151-1176. doi: 10.1007/s11469-017-9746-y

Hancock, L., \& Smith, G. (2017). Replacing the Reno model with a robust public health approach to "responsible gambling": Hancock and Smith's response to commentaries on our original Reno Model critique. International Journal of Mental Health and Addiction, 15(6), 1209-1220. doi: 10.1007/s11469-017-9836-x

Hancock, L., Schellinck, T., \& Schrans, T. (2008). Gambling and corporate social responsibility (CSR): Re-defining industry and state roles on duty of care, host responsibility and risk management. Policy and Society, 271), 55-68. doi: 10.1016/j.polsoc.2008.07.005

Hancock. L. (2011). Regulatory failure? The case of Crown Casino. Melbourne, AU: Australian Scholarly Publishing.

Harris, A., \& Griffiths, M. D. (2017). A critical review of the harmminimisation tools available for electronic gambling. Journal of Gambling Studies, 33(1), 187-221. doi: 10.1007/s10899-016-9624-8

Hing, N. (2010). The evolution of responsible gambling policy and practice: Insights for Asia from Australia. Asian Journal of Gambling Issues and Public Health, 1(1), 19-33. 10.1186/BF03342116

Korn, D., \& Shaffer, H. (1999). Gambling and the health of the public: Adopting a public health perspective. Journal of Gambling Studies, 15(4), 289-365. doi: 10.1023/A:1023005115932

Korn, D., Gibbins, R., \& Azmier, J. (2003). Framing public policy towards a public health paradigm for gambling. Journal of Gambling Studies, 19(2), 235-256. doi: 10.1023/A:1023685416816

Korn, D., Reynolds, J., \& Hurson, T. (2008). Commercial gambling advertising: Understanding the youth connection. Retrieved from http://www.greo.ca/Modules/EvidenceCentre/files/2348.pdf

Korn, D., Reynolds, J., \& Skinner, H. (2006). The Reno Model: A public health discussion. Paper presented at the 13th International Conference on Gambling and Risk-taking, Lake Tahoe, Nevada.

Ladouceur, R., Shaffer, P., Blaszczynski, A., \& Shaffer, H. J. (2017). Responsible gambling: A synthesis of the empirical evidence. Addiction Research \& Theory, 25(3), 225-235. doi: 10.1080/16066359.2016.1245294

Livingstone, C., \& Adams, P. J. (2016). Clear principles are needed for integrity in gambling research. Addiction, 111(1), 5-10. doi: 10.1111/add.12913
MacLaren, V. V. (2016). Video lottery is the most harmful form of gambling in Canada. Journal of Gambling Studies, 32(2), 459-485. doi: 10.1007/s10899-015-9560-z

Miller, H. E., Thomas, S. L., Smith, K. M., \& Robinson, P. (2016). Surveillance, responsibility and control: An analysis of government and industry discourses about "problem" and "responsible" gambling. Addiction Research \& Theory, 24(2), 163-176. doi: 10.3109/16066359.2015.1094060

Monaghan, S., Derevensky, J., \& Sklar, A. (2008). Impact of gambling advertisements and marketing on children and adolescents: Policy recommendations to minimiseharm. Journal of Gambling Issues, 22, 252-274. doi: 10.4309/jgi.2008.22.7

Reith, G. (2008). Reflections on responsibility. Journal of Gambling Issues, 22, 149-155. doi: 10.4309/jgi.2008.22.12

Reith, G. (2013). Techno economic systems and excessive consumption: A political economy of 'pathological' gambling. The British Journal of Sociology, 64(4), 717-738. doi: 10.1111/1468-4446.12050

Schellinck, T., \& Schrans, T. (1998). The 1997/98 Nova Scotia regular VL players study highlight report. Retrieved form http://stoppredatorygambling.org/wpcontent/uploads/2012/12/Novia-Scotia-Problem-GamblingStudy.pdf

Schüll, N. (2012). Addiction by design. Princeton, NJ: Princeton University Press.

Smith, G., \& Rubenstein, D. (2011). Socially responsible and accountable gambling in the public interest. Journal of Gambling Issues, 25, 5467. doi: 10.4309/jgi.2011.25.5

Statista (2018). Global gambling market gross gaming yield (GGY) from 2001 to 2019 (in billion U.S. dollars). Retrieved from

https://www.statista.com/statistics/253416/global- gamblingmarket-gross-win/

Victorian Responsible Gambling Foundation (2018). Strategic plan 2018-2021. Retrieved from

https://responsiblegambling.vic.gov.au/about-us/strategic-direction/

\section{Funding Statement}

This project was partially supported by the funding of Sylvia Kairouz's research chair on gambling granted by the Fonds de recherche du Québec - Société et culture (FQRSC) and the Social Sciences and Humanities Research Council (SSHRC) Insight grant. Jennifer Reynolds received support via a postdoctoral fellowship from the Fonds de recherche du Québec-Société et Culture (FRQ-SC; 210145) and funding Concordia University's Research Chair on Gambling and the Responsible Gaming in the Digital Era project. Sylvia Kairouz is holder of the Research Chair on Gambling Studies funded by the FRQ-SC (170115). Samantha llacqua received funding from the FRQ-SC Masters Bursary. While writing this manuscript, Martin French had support via a Social Sciences and Humanities Research Council (SSHRC) Insight Development Grant (430-2016-00996) and an ActionConcertée grant from the (FRQ-SC; 2017-BJ-202106). 


\section{Author Details}

Jennifer Reynolds is an FRQ-SC funded Postdoctoral Fellow at the Research Chair on Gambling, at Concordia University (Montreal, Canada). Trained in public health at the University of Toronto, Dr. Reynolds has over 15 years research experience on the topic of gambling prevention, with an expertise in youth. Dr. Reynolds recently developed best practices for youth gambling prevention and has produced two documentaries as gambling prevention/education resources. Her current research projects focus on the convergence between gambling and gaming, examining the complex social and environmental interactions which shapes players experience, while also engaging young people in artsbased knowledge dissemination.

Sylvia Kairouz is an associate professor in the Department of Sociology and Anthropology at Concordia University. She has published extensively in sociology, social epidemiology and public health journals and won the Brain Star Award of the Canadian Institute of Health Research for her innovative work on the role of social contexts in alcohol consumption. She is currently engaged in funded research examining comprehensive multilevel models of determinants of gambling. She has piloted six large population surveys in Quebec over the last five years and collaborates with scholars and key institutions in Quebec, Canada and internationally. She holds an FQRSC research chair on the study of gambling and is the head of the HERMES research team focusing on the online and digital forms of gambling games.

Samantha llacqua will begin her doctoral studies at Concordia University in September 2019. Her doctoral research will focus on the experience of patients with chronic illnesses as they attempt to navigate the health care system. In contrast, her Master's research involved interviews and auto-ethnographic participant observation in an on-campus sexual assault resource centre. The purpose of this research was to examine a side of the issue of sexual violence on Canadian campuses that had yet to be thoroughly explored - that being the support side. Her experience in gambling studies began during her undergraduate degree, under the supervision of Dr. Sylvia Kairouz, and continued into the beginning of her Master's studies.
Martin French is an associate professor with the Department of Sociology and Anthropology at Concordia University. His research examines the social dimensions of technology with an empirical focus on communications and information technology (CIT). It emphasizes the broader social and political contexts of CIT, focusing especially on risk, surveillance, privacy, and social justice. Recently, Martin has embarked on a study of efforts to regulate 'dangerous', 'risky', and 'contentious' forms of digitally-mediated consumption. A key set of questions underlying this study concerns what might be termed the 'gamblification' of games, the incorporation of addictive, gambling-like retention mechanics into digital games.

\section{ORCID}

Jennifer Reynolds (10) https://orcid.org/0000-0001-5363$\underline{622 X}$

Sylvia Kairouz (10 https://orcid.org/0000-0002-8788-4456 


\section{Primary references}

Adams, P. J., Raeburn, J., \& DeSilva, K. (2009). Gambling beneficiaries having their cake and eating it: The attractions of avoiding responsible gambling regulation. Addiction, 104(5), 697-698. doi:10.1111/j.1360-0443.2009.02530.x

Ariyabuddhiphongs, V. (2013). Problem gambling prevention: Before, during, and after measures. International Journal of Mental Health and Addiction, 17(5), 568-582. doi:10.1007/s11469-013-9429-2

Auer, M., \& Griffiths, M. D. (2013). Voluntary limit setting and player choice in most intense online gamblers: An empirical study of gambling behaviour. Journal of Gambling Studies, 29(4), 647-660. doi:10.1007/s10899-012-9332-y

Auer, M., Malischnig, D., \& Griffiths, M. (2014). Is "pop-up" messaging in online slot machine gambling effective as a responsible gambling strategy? Journal of Gambling Issues, (29) doi:10.4309/jgi.2014.29.3

Auer, M. M., \& Griffiths, M. D. (2016). Personalized behavioral feedback for online gamblers: A real world empirical study. Frontiers in Psychology, 7NOV) doi:10.3389/fpsyg.2016.01875

Auer, M. M., \& Griffiths, M. D. (2015). Testing normative and selfappraisal feedback in an online slot-machine pop-up in a real-world setting. Frontiers in Psychology, 6, 339. doi:10.3389/fpsyg.2015.00339

Auer, M. M., \& Griffiths, M. D. (2015). The use of personalized behavioral feedback for online gamblers: An empirical study. Frontiers in Psychology, 6Retrieved from http://0search.ebscohost.com.mercury.concordia.ca/login.aspx?direct=true\& $\mathrm{db}=$ psyh\&AN $=2016-20000-001 \&$ site $=$ ehost-live\&scope $=$ site

Blaszczynski, A., Cowley, E., Anthony, C., \& Hinsley, K. (2016). Breaks in play: Do they achieve intended aims? Journal of Gambling Studies, 32(2), 789-800. doi:10.1007/s10899-015-9565-7

Blaszczynski, A., Gainsbury, S., \& Karlov, L. (2014). Blue gum gaming machine: An evaluation of responsible gambling features. Journal of Gambling Studies, 30(3), 697-712. doi:10.1007/s10899-013-9378-5

Blaszczynski, A., Ladouceur, R., \& Shaffer, H. J. (2004). A science-based framework for responsible gambling: The reno model. Journal of Gambling Studies, 20(3), 301-317. doi:10.1023/B:JOGS.0000040281.49444.e2

Blaszczynski, A. (2005). Commentaries: To formulate gambling policies on the premise that problem gambling is an addiction may be premature. Addiction, 10099), 1230-1231. doi:10.1111/j.13600443.2005.01199.x

Blaszczynski, A., Collins, P., Fong, D., Ladouceur, R., Nower, L., Shaffer, H. J., et al. (2011). Responsible gambling: General principles and minimal requirements. Journal of Gambling Studies, 274), 565-573. doi:10.1007/s10899-010-9214-0

Blaszczynski, A., Parke, A., Harris, A., Parke, J., \& Rigbye, J. (2014). Facilitating player control in gambling. Journal of Gambling Business \& Economics, 8(3), 36-51. Retrieved from

http://search.ebscohost.com/login.aspx?direct=true \&db=bth\&AN=1 02646763\&site=bsi-live

Blaszczynski, A., Sharpe, L., Walker, M., Shannon, K., \& Coughlan, M. (2005). Structural characteristics of electronic gaming machines and satisfaction of play among recreational and problem gamblers. International Gambling Studies, 5(2), 187-198.

doi:10.1080/14459790500303378

Breen, H., Buultjens, J., \& Hing, N. (2006). Implementing responsible gambling practices in a regional area. Journal of Hospitality and Tourism Management, 13(1), 23-43. doi:10.1375/jhtm.13.1.23

Breen, H. M. (2012). Risk and protective factors associated with gambling consequences for indigenous australians in north queensland. International Journal of Mental Health and Addiction, 10(2), 258-272. doi:10.1007/s11469-011-9315-8

Breen, H., Buultjens, J., \& Hing, N. (2005). Evaluating implementation of a voluntary responsible gambling code in queensland, australia. ECOMMUNITY: International Journal of Mental Health \& Addiction, 3(1), 15-25. Retrieved from http://0-

search.ebscohost.com.mercury.concordia.ca/login.aspx?direct=true\& $\mathrm{db}=$ snh\&AN=18320882\&site=ehost-live\&scope $=$ site

Breen, H., Buultzens, J., \& Hing, N. (2005). The responsible gambling code in queensland, australia: Implementation and venue assessment. UNLV Gaming Research \& Review Journal, 9(1), 43-60.
Buchanan, J., Elliott, G., \& Johnson, L. W. (2009). The marketing of legal but potentially harmful products and corporate social responsibility: The gaming industry view. International Journal of Interdisciplinary Social Sciences, 4(2), 81-97. Retrieved from SCOPUS database.

Campbell, C. S., \& Smith, G. J. (2003). Gambling in canada, from vice to disease to responsibility: A negotiated history. Canadian Bulletin of Medical History = Bulletin Canadien d'Histoire De La Médecine, 20(1), 121-149. Retrieved from SCOPUS database.

Catherine Tay Swee Kian. (2009). New developments in casino gaming business: Singapore's approach to responsible gambling. Business Law Review, 30(5), 116-119.

Cloutier, M., Ladouceur, R., \& SÃ@vigny, S. (2006). Responsible gambling tools: Pop-up messages and pauses on video lottery terminals. The Journal of Psychology: Interdisciplinary and Applied, 140(5), 434-438. doi:10.3200/JRLP.140.5.434-438

Compton, W., Minoli, D. M., \& Goode, M. M. H. (2015). Responsible gambling laws' contributions to behaviour change in problem gamblers in online poker. (pp. 226-261) doi:10.4018/978-1-46668595-6.ch013

Crewe-Brown, C., Blaszczynski, A., \& Russell, A. (2014). Prize level and debt size: Impact on gambling behaviour. Journal of Gambling Studies, 30(3), 639-651. doi:10.1007/s10899-013-9379-4

Currie, S. R., Hodgins, D. C., Wang, J., El-Guebaly, N., \& Wynne, H. (2008). In pursuit of empirically based responsible gambling limits. International Gambling Studies, 8(2), 207-227.

doi:10.1080/14459790802172265

Currie, S. R., Hodgins, D. C., Wang, J., el-Guebaly, N., Wynne, H., \& Miller, N. V. (2008). Replication of low-risk gambling limits using canadian provincial gambling prevalence data. Journal of Gambling Studies, 24(3), 321-335. doi:10.1007/s10899-008-9091-y

Dickerson, M., \& O'connor, J. (2006). Gambling as an addictive behaviour: Impaired control, harm minimisation, treatment and prevention. (pp. 1-176) doi:10.1017/CBO9780511543715

Dufour, J., Ladouceur, R., \& Giroux, I. (2010). Training program on responsible gambling among video lottery employees. International Gambling Studies, 1011), 61-80. doi:10.1080/14459791003743037

Etches, M. W. (2013). Introduction. Journal of Gambling Business \& Economics, 7(3), i-ii.

Etches, M. W., \& Rigbye, J. L. (2014). Introduction. Journal of Gambling Business \& Economics, 8(3), 1-5.

Faregh, N., \& Leth-Steensen, C. (2009). Reflections on the voluntary selfexclusion of gamblers and the law-suits against ontario lottery and gaming corporation. Journal of Gambling Studies, 25(2), 131-138. doi:10.1007/s10899-009-9114-3

Felsher, J. R., Derevensky, J. L., \& Gupta, R. (2004). Lottery playing amongst youth: Implications for prevention and social policy. Journal of Gambling Studies, 20(2), 127-153.

doi:10.1023/B:JOGS.0000022306.72513.7c

Fletcher, J. (2013). Gambling and hospital lotteries: Looking out for losers doi:10.1503/cmaj.131102

Forsström, D., Hesser, H., \& Carlbring, P. (2016). Usage of a responsible gambling tool: A descriptive analysis and latent class analysis of user behavior. Journal of Gambling Studies, 32(3), 889-904. doi:10.1007/s10899-015-9590-6

Franco, C. A., Maciejewski, P. K., \& Potenza, M. N. (2011). Past-year recreational gambling in a nationally representative sample: Correlates of casino, non-casino, and both casino/non-casino gambling. Psychiatry Research, 188(2), 269-275. doi:10.1016/j.psychres.2011.04.008

Gainsbury, S. (2011). Player account-based gambling: Potentials for behaviour-based research methodologies. International Gambling Studies, 17(2), 153-171. doi:10.1080/14459795.2011.571217

Gainsbury, S., Aro, D., Ball, D., Tobar, C., \& Russell, A. (2015). Determining optimal placement for pop-up messages: Evaluation of a live trial of dynamic warning messages for electronic gaming machines. International Gambling Studies, 15(1), 141-158. doi:10.1080/14459795.2014.1000358 
Gainsbury, S., Parke, J., \& Suhonen, N. (2013). Consumer attitudes towards internet gambling: Perceptions of responsible gambling policies, consumer protection, and regulation of online gambling sites. Computers in Human Behavior, 29(1), 235-245.

doi:10.1016/j.chb.2012.08.010

Giroux, I., Boutin, C., Ladouceur, R., Lachance, S., \& Dufour, M. (2008). Awareness training program on responsible gambling for casino employees. International Journal of Mental Health and Addiction, 6(4), 594-601. doi:10.1007/s11469-008-9165-1

Gray, H. M., LaPlante, D. A., \& Shaffer, H. J. (2012). Behavioral characteristics of internet gamblers who trigger corporate responsible gambling interventions. Psychology of Addictive Behaviors, 26(3), 527-535. doi:10.1037/a0028545

Griffiths, M. D., Wood, R. T. A., \& Parke, J. (2009). Social responsibility tools in online gambling: A survey of attitudes and behavior among internet gamblers. Cyberpsychology and Behavior, 12(4), 413-421. doi:10.1089/cpb.2009.0062

Hancock, L., Schellinck, T., \& Schrans, T. (2008). Gambling and corporate social responsibility (CSR): Re-defining industry and state roles on duty of care, host responsibility and risk management. Policy and Society, 2オ1), 55-68. doi:10.1016/j.polsoc.2008.07.005

Hancock, L. (2013). Giving dracula the keys to the blood bank? interrogating the fifth crown casino licensing regulatory review. Journal of Business Systems, Governance \& Ethics, 8(1), 1-21.

Hao, Z., Hancock, L., \& Thompson, W. N. (2014). In search of best practices in responsible gaming (RG): A comparative study of RG among macau, las vegas, and melbourne casinos. Gaming Law Review \& Economics, 18(4), 361-368. doi:10.1089/glre.2014.1845

Harris, A., Parke, A., \& Griffiths, M. D. (2016). The case for using personally relevant and emotionally stimulating gambling messages as a gambling harm-minimisation strategy. International Journal of Mental Health and Addiction, , 1-10. doi:10.1007/s11469-016-9698-7

Hing, N. (2001). Changing the odds: A study of corporate social principles and practices in addressing problem gambling. Journal of Business Ethics, 33(2), 115-144. doi:10.1023/A:1017527429283

Hing, N., \& McMillen, J. (2002). A conceptual framework of the corporate management of social impacts: The case of problem gambling. Business \& Society Review (00453609), 1074), 457-488. Retrieved from

http://search.ebscohost.com/login.aspx?direct=true $\& d b=b t h \& A N=8$ 738528\&site=bsi-live

Hing, N., \& Nuske, E. (2011). Assisting problem gamblers in the gaming venue: A counsellor perspective. International Journal of Mental Health and Addiction, 9(6), 696-708. doi:10.1007/s11469-010-9305-2

Hing, N. (2003). Principles, processes and practices in responsible provision of gambling: A conceptual discussion. UNLV Gaming Research \& Review Journal, 71), 33. Retrieved from http://0search.ebscohost.com.mercury.concordia.ca/login.aspx?direct=true \& $\mathrm{db}=\mathrm{a9h} \& \mathrm{AN}=9616827 \&$ site $=$ ehost-live\&scope $=$ site

Hing, N., \& Breen, H. (2008). How working in a gaming venue can lead to problem gambling: The experiences of six gaming venue staff. Journal of Gambling Issues, 21, 11-29. Retrieved from http://0search.ebscohost.com.mercury.concordia.ca/login.aspx?direct=true\& $\mathrm{db}=$ psyh\&AN=2008-12768-001\&site=ehost-live\&scope $=$ site

Hing, N., Cherney, L., Gainsbury, S. M., Lubman, D. I., Wood, R. T., \& Blaszczynski, A. (2015). Maintaining and losing control during internet gambling: A qualitative study of gamblers' experiences. New Media \& Society, 177), 1075-1095. doi:10.1177/1461444814521140

Hing, N., \& Gainsbury, S. (2011). Risky business: Gambling problems amongst gaming venue employees in queensland, australia. Journal of Gambling Issues, 25, 4-23. doi:10.4309/jgi.2011.25.2

Hing, N., \& Mackellar, J. (2004). Challenges in responsible provision of gambling: Questions of efficacy, effectiveness and efficiency. UNLV Gaming Research \& Review Journal, 8(1), 43-58. Retrieved from http://0-

search.ebscohost.com.mercury.concordia.ca/login.aspx?direct=true\& $\mathrm{db}=\mathrm{a} 9 \mathrm{~h} \& \mathrm{AN}=13186601 \&$ site $=$ ehost-live \&scope $=$ site
Hing, N., \& Mattinson, A. (2005). Evaluation of the NSW ClubSafe responsible gambling program: Opportunities and challenges for new zealand clubs. ECOMMUNITY: International Journal of Mental Health \& Addiction, 3(1), 61-69. Retrieved from http://0search.ebscohost.com.mercury.concordia.ca/login.aspx?direct=true \& $\mathrm{db}=$ snh\&AN=18320887\&site=ehost-live\&scope=site

Hing, N., \& Nuske, E. (2012). Responding to problem gamblers in the venue: Role conflict, role ambiguity, and challenges for hospitality staff. Journal of Human Resources in Hospitality \& Tourism, 11(2), 146-164. doi:10.1080/15332845.2012.648896

Jardin, B., \& Wulfert, E. (2009). The use of messages in altering risky gambling behavior in college students: An experimental analogue study. American Journal on Addictions, 18(3), 243-247.

doi:10.1080/10550490902786918

Järvinen-Tassopoulos, J. (2010). Theories and ludic practices: Ethics and responsibility in games. [Des théories et des pratiques ludiques: L'Éthique et la responsabilité en jeu] Societes, 1071), 15-27. doi:10.3917/soc.107.0015

Jones, P., Hillier, D., \& Comfort, D. (2009). Corporate social responsibility in the UK gambling industry. Corporate Governance, $9(2), 189-201$. doi:10.1108/14720700910946622

Jonson, E. P., Lindorff, M., \& McGuire, L. (2012). Paternalism and the pokies: Unjustified state interference or justifiable intervention? Journal of Business Ethics, 110(3), 259-268. doi:10.1007/s10551-0111152-y

Kim, H. S., Wohl, M. J. A., Stewart, M. J., Sztainert, T., \& Gainsbury, S. M. (2014). Limit your time, gamble responsibly: Setting a time limit (via pop-up message) on an electronic gaming machine reduces time on device. International Gambling Studies, 14(2), 266-278. doi:10.1080/14459795.2014.910244

Kingma, S. F. (2015). Paradoxes of risk management: Social responsibility and self-exclusion in dutch casinos. Culture and Organization, 21(1) doi:10.1080/14759551.2013.795152

Ladouceur, R., Blaszczynski, A., \& Lalande, D. R. (2012). Pre-commitment in gambling: A review of the empirical evidence. International Gambling Studies, 12(2), 215-230. doi:10.1080/14459795.2012.658078

Ladouceur, R., Shaffer, H. J., Blaszczynski, A., \& Shaffer, P. (2016). Responsible gambling: A synthesis of the empirical evidence. Addiction Research and Theory, , 1-11. doi:10.1080/16066359.2016.1245294

Ladouceur, R., \& SÃ@vigny, S. (2005). Structural characteristics of video lotteries: Effects of a stopping device on illusion of control and gambling persistence. Journal of Gambling Studies, 21(2), 117-131. doi:10.1007/s10899-005-3028-5

Ladouceur, R., \& SÃ@vigny, S. (2006). The impact of video lottery game speed on gamblers. Journal of Gambling Issues, 17 doi:10.4309/jgi.2006.17.12

Ladouceur, R., \& SÃ@vigny, S. (2009). Electronic gambling machines: Influence of a clock, a cash display, and a precommitment on gambling time. Journal of Gambling Issues, 23, 31-41. doi:10.4309/jgi.2009.23.2

LaPlante, D. A., Gray, H. M., LaBrie, R. A., Kleschinsky, J. H., \& Shaffer, H. J. (2012). Gaming industry employees' responses to responsible gambling training: A public health imperative. Journal of Gambling Studies, 28(2), 171-191. doi:10.1007/s10899-011-9255-z

Lee, C., Back, K., Hodgins, D. C., \& Lee, T. K. (2013). Examining antecedents and consequences of gambling passion: The case of gambling on horse races. Psychiatry Investigation, 104), 365-372. doi:10.4306/pi.2013.10.4.365

Lee, C., Lee, Y., Bernhard, B. J., \& Yoon, Y. (2006). Segmenting casino gamblers by motivation: A cluster analysis of korean gamblers. Tourism Management, 27(5), 856-866. doi:10.1016/j.tourman.2005.05.009

Lee, C., Song, H., Lee, H., Lee, S., \& Bernhard, B. J. (2013). The impact of CSR on casino employees' organizational trust, job satisfaction, and customer orientation: An empirical examination of responsible gambling strategies. International Journal of Hospitality Management, 33, 406-415. doi:10.1016/j.jjhm.2012.10.011 
Lee, J., Chen, C., Song, H., \& Lee, C. (2014). The role of responsible gambling strategy and gambling passion in the online gamblers' decision-making process: Revising the theory of planned behavior. Journal of Gambling Studies, 30(2), 403-422. doi:10.1007/s10899-0139359-8

Lee, T. J., \& Kim, H. -. (2014). Problem gambling and preventive measures: The case of australia. Tourism Analysis, 1966), 791-797. doi:10.3727/108354214X14146846679727

Leino, T., Torsheim, T., Blaszczynski, A., Griffiths, M., Mentzoni, R., Pallesen, S., et al. (2015). The relationship between structural game characteristics and gambling behavior: A population-level study. Journal of Gambling Studies, 31(4), 1297-1315. doi:10.1007/s10899014-9477-y

Leung, T. C. H., \& Gray, R. (2016). Social responsibility disclosure in the international gambling industry: A research note. Meditari Accountancy Research, 24(1), 73-90. doi:10.1108/MEDAR-01-20150001

Livingstone, C., \& Woolley, R. (2007). Risky business: A few provocations on the regulation of electronic gaming machines. International Gambling Studies, 73), 361-376. doi:10.1080/14459790701601810

Makarovic, M., Macur, M., \& Roncevic, B. (2011). Policy challenges of problem gambling in slovenia. [lzazovi problema kockanja u Sloveniji] Ljetopis Socijalnog Rada, 18(1), 127-152. Retrieved from SCOPUS database.

Mauritius: Gambling law.(2008). Commonwealth Law Bulletin, 34(2), 427-475. doi:10.1080/03050710802038585

McDermott, C. (2011). Corporate social responsibility and the gambling sector -- myth or reality? Journal of Strategic Management Education, 71), 35-57. Retrieved from

http://search.ebscohost.com/login.aspx?direct=true \&db=bth\&AN=9 5985816\&site=bsi-live

Miller, H. E., Thomas, S. L., Smith, K. M., \& Robinson, P. (2016). Surveillance, responsibility and control: An analysis of government and industry discourses about "problem" and "responsible" gambling. Addiction Research and Theory, 24(2), 163-176. doi:10.3109/16066359.2015.1094060

Monaghan, S. (2008). Review of pop-up messages on electronic gaming machines as a proposed responsible gambling strategy. International Journal of Mental Health and Addiction, 6(2), 214-222. doi:10.1007/s11469-007-9133-1

Monaghan, S. (2009). Responsible gambling strategies for internet gambling: The theoretical and empirical base of using pop-up messages to encourage self-awareness. Computers in Human Behavior, 25(1), 202-207. doi:10.1016/j.chb.2008.08.008

Monaghan, S., \& Blaszczynski, A. (2009). Electronic gaming machine warning messages: Information versus self-evaluation. Journal of Psychology: Interdisciplinary and Applied, 144(1), 83-96. doi:10.1080/00223980903356081

Monaghan, S., Blaszczynski, A., \& Nower, L. (2009). Do warning signs on electronic gaming machines influence irrational cognitions? Psychological Reports, 105(1), 173-187. doi:10.2466/PR0.105.1.173187

Moodie, C., \& Reith, G. (2009). Responsible gambling signage on electronic gaming machines, before and after the implementation of the united kingdom gambling act: An observational study. International Gambling Studies, 9(1), 5-17. doi:10.1080/14459790802652183

Mulkeen, J., Abdou, H. A., \& Parke, J. (2017). A three stage analysis of motivational and behavioural factors in UK internet gambling. Personality and Individual Differences, 107, 114-125. doi:10.1016/j.paid.2016.11.007

Nisbet, S. (2009). How customers behave on the gaming floor: Revelations from employees. Journal of Travel and Tourism Marketing, 26(4), 430-444. doi:10.1080/10548400902976604

Nisbet, S. (2005). Alternative gaming machine payment methods in australia: Current knowledge and future implications. International Gambling Studies, 5(2), 229-252. doi:10.1080/14459790500303477
Nisbet, S. (2005). Responsible gambling features of card-based technologies. ECOMMUNITY: International Journal of Mental Health \& Addiction, 3(2), 54-63. Retrieved from http://0search.ebscohost.com.mercury.concordia.ca/login.aspx?direct=true\& $\mathrm{db}=$ snh \&AN=20537764\&site=ehost-live\&scope=site

O'hare, C. (2004). Self -- exclusion concept vs. reality. Gaming Law Review, 8(3), 189-191. Retrieved from http://0search.ebscohost.com.mercury.concordia.ca/login.aspx?direct=true\& $\mathrm{db}=\mathrm{a} 9 \mathrm{~h} \& \mathrm{AN}=14732790 \&$ site $=$ ehost-live $\&$ scope $=$ site

Orazi, D. C., Lei, J., \& Bove, L. L. (2015). The nature and framing of gambling consequences in advertising. Journal of Business Research, 68(10), 2049-2056. doi:10.1016/j.jbusres.2015.03.002

Orford, J. (2005). Disabling the public interest: Gambling strategies and policies for britain. Addiction, 1009), 1219-1225.

Parke, A., \& Griffiths, M. D. (2016). Identifying risk and mitigating gambling-related harm in online poker. Journal of Risk Research, , 121. doi:10.1080/13669877.2016.1200657

Parke, A., Harris, A., Parke, J., Rigbye, J., \& Blaszczynski, A. (2014). Responsible marketing and advertising in gambling: A critical review. Journal of Gambling Business \& Economics, 8(3), 21-35.

Percy, C., França, M., Dragičević, S., \& d'Avila Garcez, A. (2016). Predicting online gambling self-exclusion: An analysis of the performance of supervised machine learning models. International Gambling Studies, 16(2), 193-210. doi:10.1080/14459795.2016.1151913

Phillips, J. G., \& Landon, J. (2016). Dynamic changes in the use of online advice in response to task success or failure. Behaviour and Information Technology, 35(10), 796-806. doi:10.1080/0144929X.2016.1186734

Prior Jonson, E., Lindorff, M., \& McGuire, L. (2012). Paternalism and the pokies: Unjustified state interference or justifiable intervention? Journal of Business Ethics, 110(3), 259-268. doi:10.1007/s10551-0111152-y

Quilty, L. C., Robinson, J., \& Blaszczynski, A. (2015). Responsible gambling training in ontario casinos: Employee attitudes and experience. International Gambling Studies, 15(3), 361-376. doi:10.1080/14459795.2015.1056206

Rönnberg, S. (2005). Commentaries: Steps toward responsibility. Addiction, 1009), 1232-1233. doi:10.1111/j.1360-0443.2005.01202.x

Reith, G. (2007). Gambling and the contradictions of consumption: A genealogy of the 'pathological' subject. American Behavioral Scientist, 51(1), 33-55. doi:10.1177/0002764207304856

Reith, G. (2008). Editorial: Reflections on responsibility. Journal of Gambling Issues, 22, 149-155. doi:10.4309/jgi.2008.22.12

Responsible gaming device research report.(2008). UNLV Gaming Research \& Review Journal, 12(1), 1-56. Retrieved from http://0search.ebscohost.com.mercury.concordia.ca/login.aspx?direct=true\& $\mathrm{db}=\mathrm{a} 9 \mathrm{~h} \& \mathrm{AN}=36276238 \&$ site $=$ ehost-live \&scope $=$ site

Salmasi, A. V., \& Gillam, L. (2009). In RebolledoMendez, G Liarokapis, F DeFreitas,S. (Ed.), Machine ethics for metaverse gambling: No stake in a \$24m market? doi:10.1109/VS-GAMES.2009.39

Salmon, M., Wohl, M. J. A., Sztainert, T., \& Kim, H. S. (2015). Potential clinical applications of responsible gambling. Canadian Journal of Addiction, 6(2), 72-77. Retrieved from http://0-

search.ebscohost.com.mercury.concordia.ca/login.aspx?direct=true\& $\mathrm{db}=\mathrm{a} 9 \mathrm{~h} \& \mathrm{AN}=109985845 \&$ site $=$ ehost-live \&scope $=$ site

Selin, J. (2016). From self-regulation to regulation - an analysis of gambling policy reform in finland. Addiction Research \& Theory, 24(3), 199-208. doi:10.3109/16066359.2015.1102894

Shaffer, H. J., Ladouceur, R., Blaszczynski, A., \& Whyte, K. (2016). Extending the RENO model: Clinical and ethical applications. American Journal of Orthopsychiatry, 86(3), 297-309. doi: $10.1037 /$ ort0000123

Smith, G., \& Rubenstein, D. (2011). Socially responsible and accountable gambling in the public interest. Journal of Gambling Issues, 25, 54-67. doi:10.4309/jgi.2011.25.5

Song, H. -., Lee, C. -., Norman, W. C., \& Han, H. (2012). The role of responsible gambling strategy in forming behavioral intention: An application of a model of goal-directed behavior. Journal of Travel Research, 51(4), 512-523. doi:10.1177/0047287511418365 
Stewart, M. J., \& Wohl, M. J. A. (2013). Pop-up messages, dissociation, and craving: How monetary limit reminders facilitate adherence in a session of slot machine gambling. Psychology of Addictive Behaviors, 271), 268-273. doi:10.1037/a0029882

Stones, C. R. (2008). A study of responsible gambling in the eastern cape of south africa: A psychological and psychosocial exploration. International Journal of Interdisciplinary Social Sciences, 2(6), 85-92. Retrieved from SCOPUS database.

Thomas, S. L., Lewis, S., \& Westberg, K. (2015). 'You just change the channel if you don't like what you're going to hear': Gamblers' attitudes towards, and interactions with, social marketing campaigns. Health Expectations, 18(1), 124-136. doi:10.1111/hex.12018

Townshend, P. (2007). Self-exclusion in a public health environment: An effective treatment option in new zealand. International Journal of Mental Health and Addiction, 5(4), 390-395. doi:10.1007/s11469-0079075-7

Turner, N. E., Wiebe, J., Falkowski-Ham, A., Kelly, J., \& Skinner, W. (2005). Public awareness of responsible gambling and gambling behaviours in ontario. International Gambling Studies, 5(1), 95-112. doi:10.1080/14459790500098044

Valleur, M. (2008). Gambling, search of meaning, and addiction. [Jeu, recherche de sens, et addiction] Psychotropes, 13(3-4), 13-25. Retrieved from SCOPUS database.

Walker, D. M., Litvin, S. W., Sobel, R. S., \& St-Pierre, R. A. (2015). Setting win limits: An alternative approach to "responsible gambling"? Journal of Gambling Studies, 31(3), 965-986. doi:10.1007/s10899-0149453-6

Wardle, H., Griffiths, M. D., Orford, J., Moody, A., \& Volberg, R. (2012). Gambling in britain: A time of change? health implications from the british gambling prevalence survey 2010. International Journal of Mental Health and Addiction, 19(2), 273-277. doi:10.1007/s11469011-9319-4

Warren, K., Parush, A., Wohl, M., \& Kim, H. S. (2014). Embedded disruption: Facilitating responsible gambling with persuasive systems design doi:10.1007/978-3-319-07127-5_22

Whyte, K. (2012). The state of responsible gaming in the united states. International Gambling Studies, 12(1), 1-3.

doi:10.1080/14459795.2012.659749

Wohl, M. J. A., Davis, C. G., \& Hollingshead, S. J. (2017). How much have you won or lost? personalized behavioral feedback about gambling expenditures regulates play. Computers in Human Behavior, 70, $437-$ 445. doi:10.1016/j.chb.2017.01.025

Wohl, M. J. A., Santesso, D. L., \& Harrigan, K. (2013). Reducing erroneous cognition and the frequency of exceeding limits among slots players: A short (3-minute) educational animation facilitates responsible gambling. International Journal of Mental Health and Addiction, 11(4), 409-423. doi:10.1007/s11469-012-9424-z

Wohl, M. J. A., Gainsbury, S., Stewart, M. J., \& Sztainert, T. (2013). Facilitating responsible gambling: The relative effectiveness of education-based animation and monetary limit setting pop-up messages among electronic gaming machine players. Journal of Gambling Studies, 29(4), 703-717. doi:10.1007/s10899-012-9340-y

Wohl, M. J. A., Parush, A., Kim, H. (. S., \& Warren, K. (2014). Building it better: Applying human-computer interaction and persuasive system design principles to a monetary limit tool improves responsible gambling. Computers in Human Behavior, 37, 124-132. doi:10.1016/j.chb.2014.04.045

Wood, R. T. A., \& Griffiths, M. D. (2014). Understanding positive play: An exploration of playing experiences and responsible gambling practices. Journal of Gambling Studies, 37(4), 1715-1734. doi:10.1007/s10899-014-9489-7

Wood, R. T. A., Shorter, G. W., \& Griffiths, M. D. (2014). Rating the suitability of responsible gambling features for specific game types: A resource for optimizing responsible gambling strategy. International Journal of Mental Health and Addiction, 12(1), 94-112. doi:10.1007/s11469-013-9473-y

Wood, R. T. A., \& Wohl, M. J. A. (2015). Assessing the effectiveness of a responsible gambling behavioural feedback tool for reducing the gambling expenditure of at-risk players. International Gambling Studies, 15(2), 324-339. doi:10.1080/14459795.2015.1049191

\section{Secondary References}

Abarbanel, B., Gainsbury, S. M., King, D., Hing, N., \& Delfabbro, P. H. (2016). Gambling games on social platforms: How do advertisements for social casino games target young adults? Policy and Internet, doi:10.1002/poi3.135

Abarbanel, B., Bernhard, B., Singh, A. K., \& Lucas, A. (2015). Impact of virtual atmospherics and functional qualities on the online gambler's experience. Behaviour \& Information Technology, 34(10), 1005-1021. doi:10.1080/0144929X.2015.1046930

Abarbanel, B., \& Rahman, A. (2015). eCommerce market convergence in action: Social casinos and real money gambling. UNLV Gaming Research \& Review Journal, 19(1), 51-62. Retrieved from http://0search.ebscohost.com.mercury.concordia.ca/login.aspx?direct=true\& $\mathrm{db}=\mathrm{a} 9 \mathrm{~h} \& \mathrm{AN}=103536374 \&$ site $=$ ehost-live\&scope $=$ site

Adams, P. J., Buetow, S., \& Rossen, F. (2010). Vested interests in addiction research and policy poisonous partnerships: Health sector buy-in to arrangements with government and addictive consumption industries. Addiction, 105(4), 585-590. doi:10.1111/j.1360-0443.2009.02815.x

Back, K. -., Lee, C. -., \& Stinchfield, R. (2011). Gambling motivation and passion: A comparison study of recreational and pathological gamblers. Journal of Gambling Studies, 27(3), 355-370. doi:10.1007/s10899-010-9212-2

Benhsain, K., Taillefer, A., \& Ladouceur, R. (2004). Awareness of independence of events and erroneous perceptions while gambling. Addictive Behaviors, 29(2), 399-404. doi:10.1016/j.addbeh.2003.08.011

Braverman, J., Laplante, D. A., Nelson, S. E., \& Shaffer, H. J. (2013). Using cross-game behavioral markers for early identification of high-risk internet gamblers. Psychology of Addictive Behaviors, 273), 868-877. doi:10.1037/a0032818

Brosowski, T., Hayer, T., Meyer, G., Rumpf, H., John, U., Bischof, A., et al. (2015). Thresholds of probable problematic gambling involvement for the german population: Results of the pathological gambling and epidemiology (PAGE) study. Psychology of Addictive Behaviors, 29(3), 794-804. doi:10.1037/adb0000088

Buchanan, J., Elliott, G., \& Johnson, L. W. (2009). The marketing of legal but potentially

harmful products and corporate social responsibility: The gaming industry view.

International Journal of Interdisciplinary Social Sciences, 4(2), 81-97.

Cai, Y., Jo, H., \& Pan, C. (2012). Doing well while doing bad? CSR in controversial industry sectors. Journal of Business Ethics, 108(4), 467480. doi:10.1007/s10551-011-1103-7

De Vos, S., Crouch, R., \& llicic, J. (2016). Emotional advertising to attenuate compulsive consumption: Qualitative insights from gamblers. (pp. 99-115). Australia: doi:10.1007/978-981-10-0464-3_8

Forrest, D., \& PÃ@rez, L. (2015). Just like the lottery? player behaviour and anomalies in the market for football pools. Journal of Gambling Studies, 31(2), 471-482. Retrieved from http://0-

search.ebscohost.com.mercury.concordia.ca/login.aspx?direct=true\& $\mathrm{db}=$ psyh\&AN=2015-23801-010\&site=ehost-live\&scope =site

Gainsbury, S. M., Delfabbro, P., King, D. L., \& Hing, N. (2016). An exploratory study of gambling operators' use of social media and the latent messages conveyed. Journal of Gambling Studies, 32(1), 125141. doi:10.1007/s10899-015-9525-2

Gainsbury, S. M., King, D. L., Hing, N., \& Delfabbro, P. (2015). Social media marketing and gambling: An interview study of gambling operators in australia. International Gambling Studies, 15(3), 377-393. doi:10.1080/14459795.2015.1058409

Gupta, S. (2016). A conceptual framework that identifies antecedents and consequences of building socially responsible international brands. Thunderbird International Business Review, 58(3), 225-237. doi:10.1002/tie.21732

Hellman, M., Örnberg, J. C., \& Livingstone, C. (2017). Gambling policy studies: a field that is growing in

size and complexity. 
James, R. J. E., O'Malley, C., \& Tunney, R. J. (2016). Why are some games more addictive than others: The effects of timing and payoff on perseverance in a slot machine game. Frontier in Psychology, 7, 46.

Kirchhoff, S. M. (2013). Remote gaming and the gambling industry. (pp. 1-33). United States: Retrieved from SCOPUS

Laine, E. O., \& Nielson, R. L. (2013). Place your bets: The shaping of remote gaming and internet gambling. (pp. 1-67) Retrieved from SCOPUS

Livingstone, C., \& Adams, P. (2011). Observations on the symbiosis between government and private industries for the development of highly accessible gambling markets. Addiction, 106(1), 13-14. doi:10.1111/j.1360-0443.2010.03315.x

Luquiens, A. (2017). Is harm and harm reduction effective and what are its limits in addiction without a

product?. Alcoologie et Addictologie, 39(1), 68-77.

McMullan, J. L., \& Kervin, M. (2012). Selling internet gambling: Advertising, new media and the content of poker promotion. International Journal of Mental Health and Addiction, 19(5), 622-645. doi:10.1007/s11469-011-9336-3

Miers, D. (2003). Gaming machines in great britain: A century of change. Gaming Law Review, 72), 131-147. Retrieved from http://0search.ebscohost.com.mercury.concordia.ca/login.aspx?direct=true\& $\mathrm{db}=\mathrm{a} 9 \mathrm{~h} \& \mathrm{AN}=13140272 \&$ site $=$ ehost-live \&scope $=$ site

Miers, D. (2013). The relationship between the regulatory environment governing commercial gambling and the shape of the market in the supply and game parameters of gaming machines. Journal of Gambling Business \& Economics, 73), 111-149.

Miers, D. (2015). Regulation and the management of risk in commercial gambling in great britain. International Gambling Studies, 15(3), 422434. doi:10.1080/14459795.2015.1068352

Oh, H., Bae, J., \& Kim, S. -. (2016). Can sinful firms benefit from advertising their CSR efforts?

adverse effect of advertising sinful firms' CSR engagements on firm performance. Journal

of Business Ethics, , 1-21. doi:10.1007/s10551-016-3072-3

Platzer, M. D. (2013). Remote gambling: Industry trends and federal policy. Remote gambling: Trends, policies, and federal law (pp. 1-37). United States: Retrieved from SCOPUS

Rodrigues-Silva, N. (2017). Scratch cards in Portugal: A hidden threat. International Gambling

Studies, 17(2), 332-334.

Tammi, T., MÃøntyjÃ̋rvi, J., \& Whitfield, G. (2008). Monopoly on gambling, monopoly on problems? why did gambling problems become a matter of social concern in finland? NAT Nordisk Alkohol \& Narkotikatidskrift, 25(4), 299-310. Retrieved from http://0search.ebscohost.com.mercury.concordia.ca/login.aspx?direct=true\& $\mathrm{db}=$ psyh\&AN $=2008-16471-006 \&$ site $=$ ehost-live \&scope $=$ site

Washburn, K. (2008). Paternalism or protection? federal review of tribal economic decisions in indian gaming. Gaming Law Review \& Economics, 12(5), 435-451. doi:10.1089/glre.2008.12505 